\title{
ECHOCARDIOGRAPHIC PREDICTORS OF THE EARLY POSTOPERATIVE PERIOD IN PATIENTS AFTER CORONARY ARTERY BYPASS GRAFT SURGERY
}

DOI: 10.36740/WLek202103103

\author{
Ishenbai K. Moldotashev' ', Damir A. Osmonov' ${ }^{2}$, Nazira T. Kudaibergenova ${ }^{3}$, Asan K. Nazarov², Mustafa Unal' , \\ Aleksandr A. Sorokin ${ }^{4}$ \\ II.K. AKHUNBAEV KYRGYZ STATE MEDICAL ACADEMY, BISHKEK, KYRGYZSTAN \\ 2"BIKARD" PRIVATE CARDIAC SURGERY CLINIC, BISHKEK, KYRGYZSTAN \\ ${ }^{3}$ INTERNATIONAL SCHOOL OF MEDICINE, BISHKEK, KYRGYZSTAN \\ ${ }^{4}$ INSTITUTE OF MOUNTAIN PHYSIOLOGY AND MEDICINE OF THE NATIONAL ACADEMY OF SCIENCES KYRGYZ REPUBLIC, BISHKEK, KYRGYZSTAN
}

\begin{abstract}
The aim: The purpose of the present research was to study the results of coronary artery bypass graft (CABG) surgery depending on the degree of left ventricular ejection fraction (LVEF) reduction with the aim to identify additional echocardiographic predictors of the early postoperative period.

Materials and methods: Were fixed, the results of CABG in 97 patients operated on in the "Bikard" private clinic from March 2016 to December 2018 were the material of the research. All patients underwent $C A B G$ surgery under cardiopulmonary bypass and cardioplegia, and in the preoperative period underwent echocardiographic examination according to the standard technique on the Vivid 7 machine. Patients, in dependent of the LVEF, were divided into 3 groups: group 135 people (LVEF < 40\%), group 232 people ( 40\% < LVEF < 50\%), group 330 people (LVEF $>50 \%)$.

Results: Our studies showed that the most important echocardiographic predictors of a complicated development of the disease in the early postoperative period, in addition to LVEF of the heart, can be the size of the left ventricle and left atrial, the presence and severity of mitral regurgitation and diastolic dysfunction of the left ventricle of the heart. Conclusions: Comprehensive measurement of these echocardiographic parameters will allow more accurately predict the results of coronary artery bypass grafting in the early postoperative period.
\end{abstract}

KEY WORDS: echocardiography, cardiovascular disease, coronary artery bypass surgery, ventricular ejection fraction, mitral regurgitation

Wiad Lek. 2021;74(3 p.l):395-398

\section{INTRODUCTION}

It is known that the results of coronary artery bypass graft (CABG) surgery depend on the state of cardiac contractile function, on the degree of coronary heart disease atherosclerosis, on the presence of concomitant diseases, and other factors. Echocardiography is currently the major method for the pre-operative heart condition assessment and its parameters can serve as prognostic predictors of the outcome of CABG surgery [1]. It is believed that the accuracy of the forecast increases if the complex of echocardiographic parameters and their dynamics in pharmacological tests are taken into account [2]. It is shown that patients with significant left ventricular systolic dysfunction $(\mathrm{LVEF}<35 \%)$ have an increased risk of complications leading to death [3]. Additionally, evidence indicates that such patients after CABG surgery have satisfactory recovery in the early postoperative period [4].

\section{THE AIM}

In the present research, we have studied the results in the early postoperative period of surgical intervention in patients after underwent CABG depending on the degree of decrease in the contractile function of the left ventricle of the heart. The aim was to identify additional echocardiographic predictors of an unfavorable disease course. So, the purpose of the research is to study the results of CABG surgery depending on the degree of LVSD reduction with the aim to identify additional echocardiographic predictors of the early postoperative period.

\section{MATERIALS AND METHODS}

The material of the research was the results of CABG in 97 patients operated on in the "Bikard" private clinic from March 2016 to December 2018. All patients underwent CABG surgery under cardiopulmonary bypass and cardioplegia. All patients in the preoperative period underwent echocardiographic examination according to the standard technique on the Vivid 7 machine. Patients, depending on the left ventricular ejection fraction (LVEF), were divided into 3 groups. The first one consists of 35 people with LVEF $<40 \%$, the second group 32 people with $40 \%<\mathrm{LVEF}<$ 
Table I. Biochemical parameters of patients depending on the reduction degree in heart's LVEF.

\begin{tabular}{ccccccc}
\hline \multirow{2}{*}{ Parameter } & Group 1 & Group 2 & Group 3 & \multicolumn{3}{c}{ Differences in means } \\
\cline { 5 - 7 } & & & & Group 1-Group 2 & Group 1-Group 3 & Group 2-Group 3 \\
\hline Creatinine, $\mu \mathrm{mol} / \mathrm{L}$ & $125,8 \pm 11,3$ & $104,0 \pm 10,5$ & $99,0 \pm 9,6$ & 0,077 & 0,029 & 0,656 \\
\hline Urea, $\mu \mathrm{mol} / \mathrm{L}$ & $8,6 \pm 1,3$ & $6,6 \pm 0,6$ & $7,5 \pm 0,8$ & 0,135 & 0,415 & 0,194 \\
\hline ALT, units/L & $29,0 \pm 1,2$ & $26,0 \pm 1,3$ & $27,0 \pm 1,3$ & 0,026 & 0,133 & 0,480 \\
\hline AST, units/L & $27 \pm 1,3$ & $29 \pm 1,2$ & $26 \pm 1,3$ & 0,156 & 0,480 & 0,026 \\
\hline Cholesterol, $\mu \mathrm{mol} / \mathrm{L}$ & $6,9 \pm 1,2$ & $6,3 \pm 0,41$ & $5,9 \pm 0,9$ & 0,622 & 0,429 & 0,850 \\
\hline LDL, $\mu \mathrm{mol} / \mathrm{L}$ & $2,4 \pm 0,5$ & $2,6 \pm 0,3$ & $2,3 \pm 0,4$ & 0,699 & 0,385 & 0,735 \\
\hline HDL, $\mathrm{mmol} / \mathrm{L}$ & $1,9 \pm 1,1$ & $1,8 \pm 0,8$ & $2,1 \pm 0,9$ & 0,931 & 0,774 & 0,793 \\
\hline Triglycerides, $\mu \mathrm{mol} / \mathrm{L}$ & $2,2 \pm 1,0$ & $1,7 \pm 0,5$ & $1,9 \pm 0,7$ & 0,490 & 0,686 & 0,764 \\
\hline Blood sugar, $\mu \mathrm{mol} / \mathrm{l}$ & $7,7 \pm 2,3$ & $7,1 \pm 1,0$ & $6,7 \pm 2,1$ & 0,798 & & 0 \\
\hline
\end{tabular}

Table II. Echocardiographic parameters of the examined patients, depending on the reduction degree in heart's LVEF.

\begin{tabular}{|c|c|c|c|c|c|c|}
\hline \multirow[b]{2}{*}{ Parameter } & \multirow{2}{*}{$\begin{array}{c}\text { Group } 1 \\
\mathbf{M} \pm \mathbf{m}\end{array}$} & \multirow{2}{*}{ 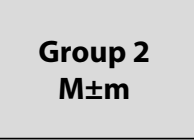 } & \multirow{2}{*}{$\begin{array}{c}\text { Group } 3 \\
\mathbf{M} \pm \mathbf{m}\end{array}$} & \multicolumn{3}{|c|}{ Differences in means } \\
\hline & & & & $\begin{array}{c}1^{\text {st }} \text { and } \\
2^{\text {nd }} \text { group }\end{array}$ & $\begin{array}{c}1^{\text {st }} \text { and } \\
3^{\text {rd }} \text { group }\end{array}$ & $\begin{array}{c}2^{\text {nd }} \text { and } \\
3^{\text {rd }} \text { group }\end{array}$ \\
\hline & & & & \multicolumn{3}{|c|}{ ANOVA } \\
\hline Age, units & $63,6 \pm 1,6$ & $63,3 \pm 1,3$ & $61,7 \pm 1,5$ & 0,983 & 0,665 & 0,778 \\
\hline Body mass index & $31,2 \pm 1,2$ & $30,2 \pm 3,0$ & $32,3 \pm 2,1$ & 0,566 & 0,461 & 0,949 \\
\hline EDD & $57,3 \pm 0,8$ & $56,0 \pm 0,7$ & $50,4 \pm 0,7$ & 0,518 & 0,000 & 0,000 \\
\hline ESD & $43,1 \pm 0,9$ & $40,8 \pm 1,2$ & $34,3 \pm 0,7$ & 0,245 & 0,000 & 0,000 \\
\hline Intraventricular septum & $10,1 \pm 0,2$ & $10,9 \pm 0,4$ & $9,9 \pm 0,3$ & 0,132 & 0,904 & 0,062 \\
\hline Posterior wall & $10,0 \pm 0,2$ & $10,8 \pm 0,3$ & $9,4 \pm 1,8$ & 0,057 & 0,995 & 0,056 \\
\hline Ejection fraction & $35,7 \pm 0,7$ & $45,1 \pm 0,3$ & $54,9 \pm 0,8$ & 0,000 & 0,000 & 0,000 \\
\hline \multirow[t]{2}{*}{ Left atrium } & $43,0 \pm 1,1$ & $39,5 \pm 0,8^{*}$ & $38,2 \pm 1,1$ & 0,048 & 0,004 & 0,654 \\
\hline & & & & \multicolumn{3}{|c|}{ z-criterion } \\
\hline Diastolic function & $\begin{array}{c}0,571 \\
(0,408-0,720)\end{array}$ & $\begin{array}{c}0,656 \\
(0,483-0,796)\end{array}$ & $\begin{array}{c}0,800 \\
(0,627-0,905)\end{array}$ & 0,476 & 0,049 & 0,205 \\
\hline $\begin{array}{c}\text { Insufficiency } \\
\text { (Regurgitation) }\end{array}$ & $\begin{array}{c}0,743 \\
(0,579-0,869)\end{array}$ & $\begin{array}{c}0,781 \\
(0,612-0,890)\end{array}$ & $\begin{array}{c}0,500 \\
(0,331-0,668)\end{array}$ & 0,713 & 0,043 & 0,021 \\
\hline
\end{tabular}

Note. $\mathrm{M} \pm \mathrm{m}$ - mean \pm standard error

$50 \%$, and the third group 30 people with LVSD $>50 \%$. Average, standard deviations and standard errors of the mean were calculated as descriptive statistics for quantitative variables. Differences in means were performed by one-way ANOVA test. The Scheffe test was used as a Post Hoc test. The critical level was taken equal to 0.05 . The calculations were carried out in the SPSS 16 program environment.

The calculations for the qualitative variables were carried out on the website http://vassarstats.net/. Fractions were calculated; 95\% confidence intervals for fractions and the proportions were compared using the Z-criterion according to the rules on the website.

\section{RESULTS}

The studied groups of patients did not significantly differ in age, body mass index (BMI), biochemical parameters (urea, aspattataminotranferase (AST), total cholesterol, low-density lipoproteins (LDL), high-density lipoprotein (HDL), triglyceride, blood sugar consists). A significant difference between the first and the third groups was in creatinine and between the first and second groups in alaninaminotranferase (ALT) (Table I).

According to echocardiographic parameters, a statistically significant difference between the groups was in LVEF, left ventricle end-diastolic dimension (LV EDD), left ventricle end-systolic dimension (LV ESD), left atrium (LA), mitral regurgitation, and left ventricular diastolic dysfunction (Table II).

After CABG surgery, three people died in the first group of patients with LVEF lower than $40 \%$, (one person in the hospital, and two after being discharged from the hospital for a month), three patients felt worse after the surgery than before, and the rest of the patients showed improvement of general well-being. In the second and third groups, there were no fatal cases, and almost all of them 
improved their functional condition in the postoperative period. Biochemical analysis data (increased creatinine and ALT) in patients with low LVEF (less of $40 \%$ ) indicate that they have renal and hepatic dysfunction. The results of our echocardiographic researches showed that, along with a low LVEF, predictors of a complicated course of the disease in the early postoperative period can be LV dimensions ( $\mathrm{LV}$ EDD and LV ESD), LA dimension, mitral regurgitation and left ventricular diastolic dysfunction. Thus, according to our data, the group of patients with low LVEF $(<40 \%)$, had statistically larger LV dimensions (LV EDD $=57.3 \pm$ $0.8 \mathrm{~mm}$ and LV ESD $=43.1 \pm 0.9 \mathrm{~mm}$ compared to the $3 \mathrm{rd}$ group: $\mathrm{LV} \mathrm{EDD}=50.4 \pm 0.7 \mathrm{~mm}$ and $\mathrm{LV} \mathrm{ESD}=34.3 \pm 0.7$ $\mathrm{mm}, \mathrm{p}<0.001)$, and LA $(43.01 \pm 1.1 \mathrm{~mm}$ compared to the 2nd 3rd groups, respectively, $39.5 \pm 0.8 \mathrm{~mm}$ and $38.2 \pm 1.1$ $\mathrm{mm} ; \mathrm{p}<0.001)$. Mitral regurgitation and left ventricular diastolic dysfunction were recorded much more often in the 1st and 2nd groups of patients compared with patients with preserved left ventricular systolic function $(\mathrm{p}<0.05)$. It should be emphasized that the severity of mitral regurgitation and diastolic dysfunction was also higher in the group of patients with low LVEF.

\section{DISCUSSION}

It is known that patients with low LV contractility are at high risk and the mortality rate and complications after CABG surgery are higher than in patients with preserved LVEF [1-4]. Moreover, there is data about the family-depending of early heart disease development. There were registered more younger development of cardiovascular syndrome in case different heart diseases have been found in the family anamnesis [5]. Gratti G et al. [6] studied 4383 cases with multiple coronary heart disease who underwent CABG in the period from January 1999 to September 2014. 300 patients (mean age $66.1 \pm 9.6$ years) had LVSD $\leq$ $35 \%$. Hospital mortality in the period of $6.2 \pm 4$ years was $5.3 \%$. The most frequent postoperative complications were prolonged invasive ventilation (17.7\%), acute renal failure (14.7\%), and multiple hemotherapy (21.3\%). Vickneson et al. [7] conducted a retrospective analysis of 346 patients with low EF ( $\leq 30 \%)$ in the period from 2019 to 2015 . It was shown that patients with significant LV dysfunction who underwent $C A B G$ surgery had a full recovery within a month. The most significant predictors of mortality were hemodynamic instability and renal dysfunction.

According to our previous studies, the overall hospital mortality after CABG surgery was $3.4 \%$, which is comparable to world standards, does not exceed 1-3\% [6, 9]. At the same time, according to our materials, the mortality rate among patients with low LVEF $(<40 \%)$ reached 8.6\% (3 persons out of 35 patients). The main cause of death in our patients after myocardial revascularization was heart failure caused by systolic or diastolic cardiac dysfunction. In recent years, the problem of diastolic dysfunction received greater attention. It was proved that in the postperfusion period, diastolic dysfunction can be caused by ischemic and reperfusion injury, hypothermia, metabolic disorders or myocardial edema and is an independent factor in the development of difficulties when disconnecting a patient from cardiopulmonary bypass machine, the use of high doses of inotropic support and an increased risk of complications [1]. It was shown that left ventricular diastolic dysfunction is a powerful predisposing factor for the development of postoperative atrium fibrillation. It was established that diastolic dysfunction in cardiac surgery patients increases postoperative mortality [8]. In more than 500 patients who underwent coronary artery bypass grafting surgery without the use of cardiopulmonary bypass machine, the E/e'> 15 according to tissue Doppler echocardiography and high diastolic pressure were associated with a high risk of postoperative complications [9]. According to a multivariate analysis of a number of researchers, left ventricular diastolic dysfunction is the best predictor of hemodynamics after cardiac surgery compared with systolic dysfunction [10]. The inclusion of measurement of indicators of diastolic function of the left ventricle in cardiac surgery patients can improve the prognosis after heart surgery and help prevent adverse events in the postoperative period $[11,12]$. It was showed that low volume characteristics of the left ventricle against the background of restrictive diastolic myocardial dysfunction are the echocardiographic predictors of poor prognosis in patients with coronary heart disease in the near term after myocardial revascularization [1].

Patients with mitral regurgitation in combination with coronary heart disease have a higher mortality rate. Thus, more than $40 \%$ of patients with coronary heart disease with severe mitral regurgitation die during the first year after the mitral regurgitation was formed [13, 14]. In the case of a combination of coronary heart disease with moderate mitral regurgitation, the mortality rate is about $15-18 \%$, mild mitral regurgitation is $8-11 \%$, while the mortality rate in patients with coronary heart disease without mitral regurgitation is approximately $5 \%$ [15]. The results of several studies convincingly showed that moderate ischemic mitral regurgitation affects the increased risk of mortality from cardiovascular diseases, including in patients with heart failure [16]. Our data confirmed that the presence and severity of mitral regurgitation is one of the important prognostic predictors of complications in the early postoperative period after CABG surgery.

\section{CONCLUSIONS}

The results of our studies showed that the most important echocardiographic predictors of a complicated course of the disease in the postoperative period, in addition to LVEF of the heart, maybe the sizes of the LV and LA, the presence and severity of mitral regurgitation and diastolic dysfunction of the LV.

According to our data, LV EDD and LVEF between the 1st and 2nd groups of patients did not achieve a statistically significant difference. At the same time, the LA dimension in these groups of patients was significantly different. Based on these results, we can assume that LA size is a more sensitive prognostic criterion for the course of the disease in the early postoperative period than LV dimension. 
Has to be noted, overall hospital mortality after CABG surgery in our study wasn't more than the all-world range and made up $3.4 \%$, but the mortality rate among patients with low LVEF $(<40 \%)$ reached $8.6 \%$ (3 persons out of 35 patients).

So, left ventricular diastolic dysfunction is a powerful predisposing factor for the development of postoperative atrium fibrillation, and dysfunction in cardiac surgery patients increases postoperative mortality.

Comprehensive measurement of these echocardiographic parameters will allow more accurately predict the results of coronary artery bypass grafting in the early postoperative period.

\section{REFERENCES}

1. Bockeria L.A., Sokolskaya N.O., Kopylova N.S. Ekhokardiograficheskiye prediktory tyazhesti rannego posleoperatsionnogo perioda u bol'nykh posle khirurgicheskoy revaskulyarizatsii miokarda. [Echocardiographic predictors of the severity of the early postoperative period in patients after surgical myocardial revascularization]. AnesthesiologyReanimatology. 2015;5:8-11. (in Russian).

2. Bukhovets I.L.,Vorozhtsova I.N., Lavrov A.G. et al. Ekhokardiograficheskiye aspekty remodelirovaniya levogo zheludochka u bol'nykh sishemicheskoy bolezn'yu serdtsa do i posle korrigiruyushchikh operatsiy na serdtse. [Echocardiographic aspects of left ventricular remodeling in patients with ischemic heart disease before and after corrective heart surgery]. ComplexProblemsCardiovascularDiseases. 2013;4:109-116. (in Russian).

3. Bystrov $D$. Aortokoronarnoye shuntirovaniye na rabotayushchem serdtse bez iskusstvennogo krovoobrashcheniya u bol'nykh so snizheniyem fraktsii vybrosa levogo zheludochka. [Coronary artery bypass grafting off-pump without cardiopulmonary bypass in patients with reduced LVSD]. PhD dissertation. Moscow. 2014: $138 \mathrm{p}$.

4. Volkov A. Koronarnoye shuntirovaniye patsiyentov s vysokim riskom razvitiya oslozhneniy. [Coronary artery bypass grafting in patients with a high risk of complications]. Doctoral dissertation. St. Petersburg. 2014: $304 \mathrm{p}$.

5. Hrechanina $0 .$, Isayeva G., Kolesnikova $0 .$, Isakova Y. Relations between familial hypercholesterolemia and early ichemic heart disease: an analysis of medical documentation data. Serbian Journal Experimental Clinical Research. 2019 .doi: 10.2478/sjecr-2019-0056.

6. Gratti G, Maschietto L., Dell Angela L. et al. Predictors of immediate and long-term outcomes of coronary bypass surgery in patients with left ventricular dysfunction. Heart Vessels. 2016;31(7):1045-1055. https:// doi.org/10.1007/s00380-015-0714-9.

7. Vickneson K., Chan S.P., Li Y. et al. Coronary artery bypass grafting in patients with low ejection fraction: what are the risk factors? J CardiovascSurg (Torino). 2019;60(3):396-405. D0I: 10.23736/s00219509.19.10670-2.

8. Rowlens M., Suri R.M., Seward J.B. et al. Patophysiological mechanism underlying initiation of new onset post-operative atrial fibrillation. J.AM. Coll Cardiol. 2011;58:9(23):953-961. doi: 10.1016/j.jacc.2011.05.021.

9. Jun N.H., Shim J.K., Kim J.C. Prognostic value of a tissue Doppler-derived index of left ventricular filling pressure on composite morbidity after off-pump coronary artery bypass surgery. BritishJournalAnaesthesia. 2011;107(4):1020-1029. https://doi.org/10.1093/bja/aer188.

10. Titova A.L.,Saiganov S.A. Diastolicheskaya funktsiya levogo zheludochka u bol'nykh ishemicheskoy bolezn'yu serdtsa, podvergshikhsya operatsii aorto-koronarnogo shchuntirovaniya. [Diastolic function of the left ventricle in patients with ischemic heart disease who underwent coronary artery bypass grafting]. RussianFamilyDoctor. 2014;3:10-17. (in Russian).
11. Skubas N.J., Shernan S.K., Mahmood F. Prioperative assessment of diastolic dysfunction. A\&A. 2011;11(3):449-472. doi: 10.1213/ ANE.0b013e31822649ac.

12. Beran E., Kapitan M., Machler H. et al. Acurate preoperative echocardiography has more impact on prediction of long-term mortality than intra-operatively measured flow in coronary bypass grafts. Eur.Cardiothorac.Surg. 2011;40(1):245-248. doi: 10.1016/j. ejcts.2010.11.001.

13. Makhmudov Sh. Otsenka sostoyaniya mitral'nogo klapana v otdalennom periode posle korrektsii ishemicheskoy mitral'noy nedostatochnosti pri operatsiyakh AKSH u bol'nykh IBS. [Assessment of the state of the mitral valve in the long-term period after correction of ischemic mitral insufficiency during $C A B G$ surgery in patients with coronary heart disease]. PhD dissertation. Moscow. 2017: 104 p. (in Russian).

14. Isayeva G.S. The state of coronary arteries in perimenopausal women with chest pain. JClinMedRes. 2014;6(6):451-455. doi: 10.14740/ jocmr1915w.

15. Sukhanov S.G., Timofeeva I.V. Dinamika umerennoy ishemicheskoy mitral'noy regurgitatsii v rannem i otdalennom periode posle koronarnogo shuntirovaniya. [Dynamics of moderate ischemic mitral regurgitation in the early and late period after coronary artery bypass grafting]. BulletinBakoulevCenterCardiovascularDiseases. 2007;8(1):4751. (in Russian).

16. Khutsurauli E. Progressirovaniye nedostatochnosti mitral'nogo klapana u bol'nykh IBS posle operatsii AKSH i khirurgicheskoy rekonstruktsii levogo zheludochka: faktory riska, mekhanizmy razvitiya, strategiya profilaktiki. [Mitral valve insufficiency advance in patients with coronary artery disease after $C A B G$ and surgical reconstruction of the left ventricle: risk factors, mechanisms of development, prevention strategy]. Abstract of PhD Dissertation. Moscow. 2012: 23 p.

\section{ORCID and contributionship:}

Ishenbai K. Moldotashev: 0000-0001-5525-3599 A, D, E,F

Damir A. Osmonov: 0000-0001-6715-722X ${ }^{B, D}$

Nazira T. Kudaibergenova: 0000-0002-2180-3377 ${ }^{B, E, D}$

Asan K. Nazarov: 0000-0002-6949-2678 ${ }^{B}$

Mustafa Unal: 0000-0002-1622-6923 ${ }^{B, D}$

Aleksandr A. Sorokin: 0000-0002-9682-8085 ${ }^{\mathrm{C}}$

\section{Conflict of interest:}

The Authors declare no conflict of interest.

\section{CORRESPONDING AUTHOR} Ishenbai K. Moldotashev

I.K.Akhunbaev Kyrgyz State Medical Academy

92, Akhunbaev St., 720020 Bishkek, Kyrgyz Republic

tel: (996)500 880604

e-mail:moldotashev@rambler.ru

Received: 29.09.2020

Accepted: 02.02.2021

A - Work concept and design, B - Data collection and analysis, C - Responsibility for statistical analysis,

D-Writing the article, $\mathbf{E}$-Critical review, $\mathbf{F}-$ Final approval of the article 